\title{
Multiple Eruptive and Vulvar Syringomas and the incipient role of dermoscopy in diagnosis
}

\author{
Paula Majluf ${ }^{1}$, Andrea Antúnez ${ }^{1}$, Hernán Herrera², Sergio Alvarez ${ }^{1}$, Alvaro Abarzúa ${ }^{1}$, Sergio González ${ }^{3}$
}

\section{Resumen}

Introducción: Los siringomas son tumores benignos derivados de la porción intraepidérmica de los conductos sudoríparos ecrinos. Ocasionalmente pueden iniciar de forma súbita como siringomas eruptivos o localizarse en sitios atípicos que retrasan el diagnóstico por años. La dermatoscopía tiene un rol incipiente en diferenciar siringomas de su extenso diagnóstico diferencial.

Métodos: Estudio retrospectivo descriptivo de serie de casos de siringomas de localización atípica. Los datos fueron extraídos de fichas clínicas electrónicas. Todos incluyen dermatoscopía y correlación histopatológica.

Resultados: Cinco pacientes. Cuatro hombres y una mujer entre 40 y 79 años de edad con siringomas atípicos: cuatro casos eruptivos y un caso de siringomas vulvares.

Discusión: Proponemos la dermatoscopía basada en nuestros hallazgos como una herramienta útil con estructuras ovales amarillas y una pseudo-red café clara difusa en su superficie. Estas estructuras amarillas se pueden correlacionar con la proliferación ductal ecrina y el denso estroma en la histopatología.

Conclusión: Enfatizamos que se debe considerar esta entidad en el diagnóstico diferencial de dermatosis papulares y conocer sus manifestaciones clínicas para optimizar la sospecha diagnóstica.

Palabras claves: Siringoma; Vulvar; Dermatoscopía

\section{SUMMARY}

Introduction: Syringomas are common benign tumors, probably of origin derived from the intraepidermal portion of the eccrine sweat ducts. Occasionally they may develop suddenly and extensively as eruptive syringomas or be located in atypical sites delaying the diagnosis for years. Dermoscopy has an incipient role in differentiating syringomas from their extensive differential diagnosis.

Methods: Retrospective descriptive case-series study of atypical location syringomas. Data extraction from clinical history from electronic files. They all include dermoscopy and histopathological correlation.

Results: Five patients: Four men and one woman between 40 and 79 years old, with atypical syringomas diagnosis: four eruptive and one vulvar syringomas.

Discussion: We propose dermoscopy, based on our findings, as a useful tool to this entity, with its oval yellow structures and a diffuse light-brown network-like structure on its surface. These yellow enlargements may be correlated with the ductal eccrine proliferation and the dense stroma seen in the histopathology.

Conclusion: We emphasize that they should be considered in the differential diagnosis of papular dermatosis, as they tend to be underdiagnosed, and to know their clinical manifestations to optimize the diagnostic suspicion.

Key words: Syringoma; Vulva; Dermoscopy
'Dermatology Department, Pontificia Universidad Católica de Chile. ${ }^{2}$ General Practitioner, Cesfam Bellavista. ${ }^{3}$ Pathological Anatomy Department, Pontificia Universidad Católica de Chile.

Trabajo no recibió financiamiento. Los autores declaran no tener conflictos de interés.

Recibido el 13 de octubre de 2019, aceptado el 15 de abril de 2020.

Corresponding author:

Paula Majluf

Cáceres

Address: Vicuña Mackenna 4686, Macul, Centro Médico San Joaquin e-mail address: pamajluf@uc.cl Full Postal: 8320000. 
$\mathrm{S}$ yringomas are common benign tumors, probably of eccrine origin derived from the intraepidermal portion of the eccrine sweat ducts. ${ }^{1,2}$ They are usually sporadic, but some familial cases have also been reported. The incidence of syringomas appears to be higher in Asians and African-Americans. ${ }^{1}$

There are more common in women and usually appears at/or after puberty as multiple localized light-brown or skin-colored papules usually found around the eyelids and cheeks. ${ }^{2}$ They may occasionally be eruptive syringomas $^{2}$, a rare variant, which develops as a multiple, small, skin-colored to reddish brown papules on the neck, chest, anterior trunk, axillae, the extremities or on the vulva ${ }^{1}$.

Vulvar syringomas, an atypical syringoma, have been poorly reported. They commonly appear as multiple symmetrical brown papules on the labia majora ${ }^{3}$. They may be asymptomatic but sometimes pruritus predates diagnosis for several years thus they may be misdiagnosed as other pruritic papular lesions of the vulva².

Dermoscopy might be helpful to distinguish syringomas from their extensive differential diagnosis. Some isolated structures have been described: yellow oval structures on a pink background ${ }^{3}$, or an homogeneous brown pigmentation with multifocal whitish areas $^{4}$. These dissimilar findings have not yet been correlated with the histopathology of the tumor.

\section{Patients and Methods}

\section{Type of study}

Retrospective descriptive epidemiological study of case series on five patients with eruptive in atypical location syringomas.

\section{Study population}

A total of 5 cases patients diagnosed with syringomas and registered in the Dermatology department of the Clinical Hospital of the Pontifical Catholic University of Chile, during the period from January 2017 to July 2018.

\section{Inclusion and exclusion criteria}

The diagnosed patients were applied the following inclusion criteria: a) extra-orbital location syringomas; b) eruptive and vulvar; c) dermoscopy and biopsy confirming syringomas.

The exclusion criteria: a) face location syringomas; b) express proof of not participating in this study.

\section{Variables}

The selected variables were sex, age, physical examination, characteristics of dermoscopy and biopsy.

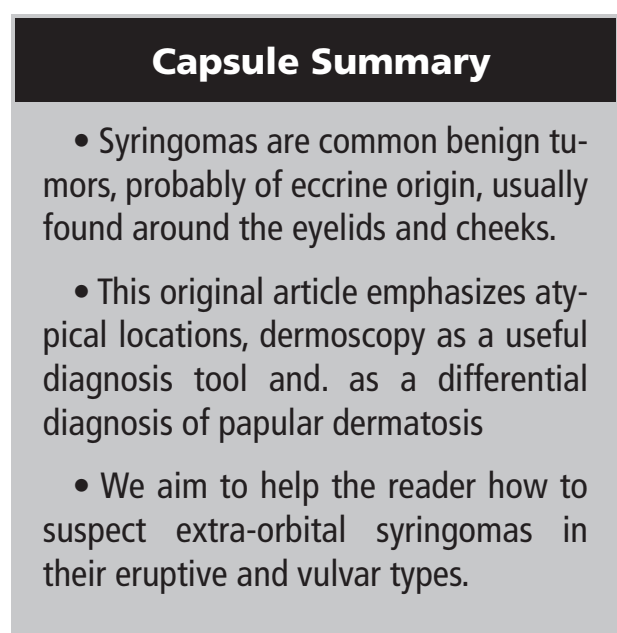

\section{Data collect}

Data extraction was performed systematically through the clinical history contained in the electronic files, photographs of the lesions with the dermatology chamber in conjunction with the use of the DermLite DL4 dermatoscope. The images were analyzed by two dermatologists of the departmen and histopathological evaluation.

\section{Analysis of data}

A descriptive statistic was made with calculation of measures of central tendency, dispersion and frequencies. The calculations were made with the statistical program SPSS Statistics 22.

\section{Results}

We present our case-series of syringomas in atypical location evaluated in our dermatologic center, Pontificia Universidad Católica de Chile. Five patients between 40 and 79 years old, four men and one women, during the January 2017 and December 2018, were chosen. They all include dermoscopy and histopathological correlation.

The number of patients in our study with atypical syringomas was 5 , with a male / female ratio of $4: 1$. The age range of consultation was between 40 and 79 years old, with an average age of $55.4(\mathrm{SD}=18.57)$ years. It was found that in $80 \%$ of the patients they had more than 10 years of evolution of the lesions. 
$60 \%$ of the syringomas were located in the chest, $40 \%$ in the arms. In dermatoscopy, yellow-brown backround is observed in $80 \%$ of cases.

\section{Case 1}

A 40-years old, man, refered asymptomatic multiple lesions in arms and trunk since 10 years. Physical examination showed multiple non-confluent pigmented papules in chest and arms. Dermoscopy revealed yellow-brown background with a light brown network on the surface. (Figure.1a-b). He had a biopsy from another center compatible with syringomas.

\section{CASE 2}

A 44-years old, man, was evaluated for a 20-year history of asymptomatic papular dermatosis, involving the trunk and upper extremities. Physical examination revealed multiple brown-erythematous, flat-topped monomorphic papules of 2-4mm in diameter in chest and upper arms. Dermoscopy: yellow-brown background with a light brown network on the surface. Histopathology: multiple small ducts lined by cubic epithelium, some with amorphous keratinous material in their lumina in a fibrous stroma. (Figure.2)

\section{Gase 3}

A 72-years old, man, asked for lesions of 7 years of evolution, asymptomatic.

Physical examination showed numerous brownish indurated non-follicular papules in chest, and in smaller amount in back. Dermoscopy: yellow-brown background with a light brown network on the surface.

The histological sample revealed small eccrine ductal structures limited to upper dermis compatible with syringomas.

\section{Case 4}

A 42-years old, woman, consulted for asymptomatic lesions in the genital area of 10 years duration, concerned that they were malignant entities, without similar lesions in other body areas. Physical examination

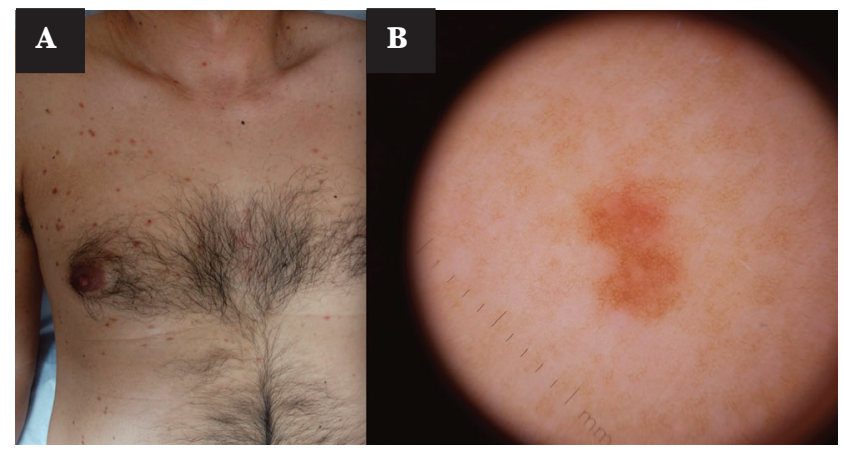

\section{Figure 1}

A. Multiple non-confluent pigmented papules in chest and arms. B. Yellow-brown background with a light brown network on the surface

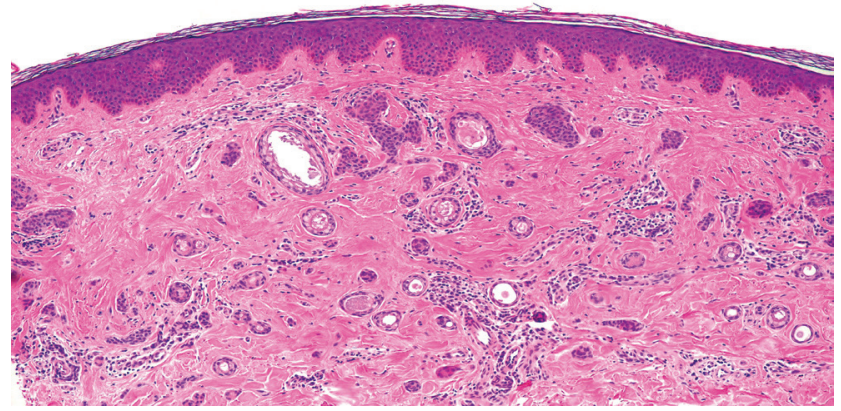

\section{Figure 2}

Histological examination of this specimen revealed multiple small ducts lined by cubic epithelium, some with amorphous keratinous material in their lumina in a fibrous stroma

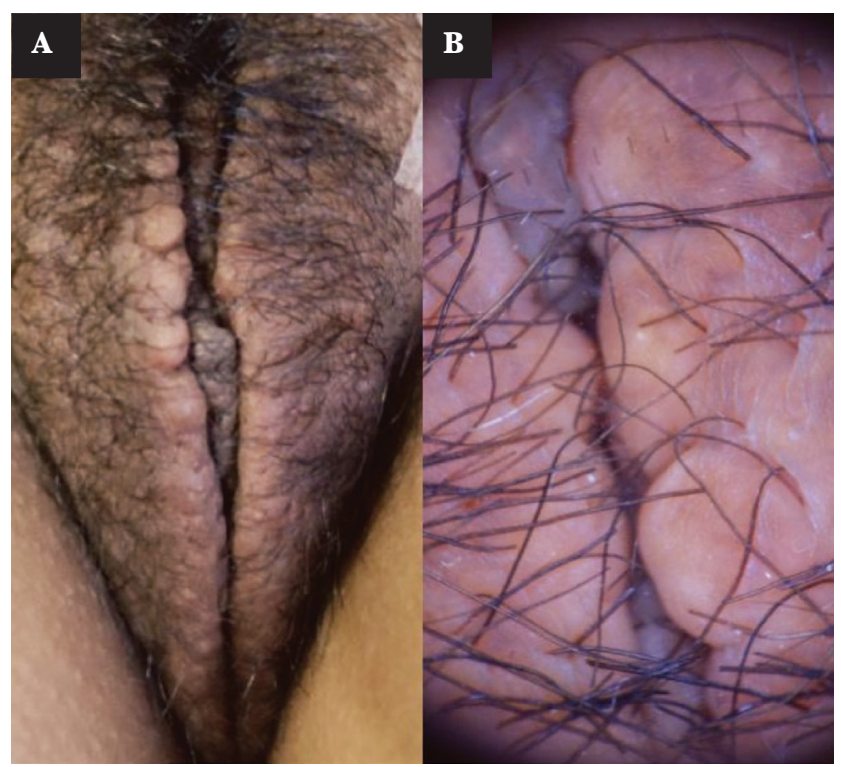

Figure 3

A. Physical examination showed skin-brownish colored papules, symmetrically distributed on the labia majora.

B. Dermoscopy revealed multiple, different sized oval bright yellow structures 
showed skin-brownish colored papules, symmetrically distributed on the labia majora (Figure.3a). Dermoscopy revealed multiple, different sized oval bright yellow structures (Figure.3b). Histological examination showed ductal structures coated by cubic epithelium with proteinaceus secretion, some of them in "tadpole" shape.

\section{Gase 5}

A 79-years old, man, with no relevant medical history, was evaluated for a 10-year history of asymptomatic papular lesions, in the abdomen. Physical examination revealed multiple, yellow-brown, flat-topped monomorphic papules of $2-4 \mathrm{~mm}$ in diameter, linearly distributed in the upper abdomen. Dermoscopy revealed yellow-brown background with a light brown network on the surface. Histopathology revealed small eccrine ductal structures in "lady mirror" compatible with syringomas.

We present a summary of the case series (Table 1)

\section{Discussion}

Eruptive syringomas are a rare subtype 1. Friedman and Butler proposed a classification of syringomas according to their clinical features and associations, consisting of four principal clinical variants: a localized form, a familial form, a form associated with Down syndrome, and a generalized form (encompassed multiple and eruptive syringomas) $)^{2,3,5}$.

The prevalence of atypical syringomas is underestimated, because they tend to be underdiagnosed. As they have been described in association with extragenital locations, the vulva should always be examined when syringomas are found in the rest of the body.

Three forms of clinical manifestations of syringomas have been described: (1) Multiple papules with symmetrical arrangement, (2) milium-like variant, and (3) lichenoid papules. These cases showed the "papular form" with symmetrical disposition which is generally asymptomatic, but it must be considered that $70 \%$ of

Table 1

\begin{tabular}{|c|c|c|c|c|c|c|}
\hline Case & Sex & $\begin{array}{c}\text { Age } \\
\text { (years) }\end{array}$ & $\begin{array}{c}\text { Evolution } \\
\text { (years) }\end{array}$ & $\begin{array}{c}\text { Physical exami- } \\
\text { nation }\end{array}$ & Dermoscopy & Histopathology \\
\hline 1 & M & 40 & 10 & $\begin{array}{l}\text { Multiple non-confluent } \\
\text { pigmented papules in } \\
\text { chest and arms }\end{array}$ & $\begin{array}{l}\text { Yellow brown back- } \\
\text { ground with a light } \\
\text { brown network on the } \\
\text { surface }\end{array}$ & $\begin{array}{l}\text { Extrasystem biopsy } \\
\text { compatible with syrin- } \\
\text { gomas. }\end{array}$ \\
\hline 2 & M & 44 & 20 & $\begin{array}{l}\text { Multiple, brown-ery- } \\
\text { thematous, flat-topped } \\
\text { monomorphic papules } \\
\text { of } 2-4 \mathrm{~mm} \text { in diam- } \\
\text { eter in chest and upper } \\
\text { arms. }\end{array}$ & idem & $\begin{array}{l}\text { Small eccrine ductal } \\
\text { structures limited to up- } \\
\text { per dermis compatible } \\
\text { with syringomas. }\end{array}$ \\
\hline 3 & $\mathrm{M}$ & 72 & 7 & $\begin{array}{l}\text { Numerous brownish } \\
\text { indurated non-follicular } \\
\text { papules in chest, and in } \\
\text { smaller amount in back }\end{array}$ & idem & $\begin{array}{l}\text { Ductal structures coated } \\
\text { by cubic epithelium } \\
\text { with proteinaceus se- } \\
\text { cretion, some of them } \\
\text { in "tadpole" shape }\end{array}$ \\
\hline 4 & $\mathrm{~F}$ & 42 & 10 & $\begin{array}{l}\text { Skin-brownish colored } \\
\text { papules, symmetrically } \\
\text { distributed on the labia } \\
\text { majora }\end{array}$ & $\begin{array}{l}\text { Multiple, different } \\
\text { sized oval bright yellow } \\
\text { structures }\end{array}$ & $\begin{array}{l}\text { Ductal structures coated } \\
\text { by cubic epithelium } \\
\text { with proteinaceus se- } \\
\text { cretion, some of them } \\
\text { in "tadpole" shape }\end{array}$ \\
\hline 5 & M & 79 & 10 & $\begin{array}{l}\text { Multiple, yellow- } \\
\text { brown, flat-topped } \\
\text { monomorphic papules } \\
\text { of 2-4mm in diameter, } \\
\text { linearly distributed in } \\
\text { the upper abdomen. }\end{array}$ & $\begin{array}{l}\text { Yellow-brown back- } \\
\text { ground with a light } \\
\text { brown network on the } \\
\text { surface. }\end{array}$ & $\begin{array}{l}\text { Small eccrine ductal } \\
\text { structures in "lady mir- } \\
\text { ror" compatible with } \\
\text { syringomas. }\end{array}$ \\
\hline
\end{tabular}


vulvar syringomas presents pruritus. Thus, they should be suspected in the differential diagnosis of vulvar pain syndrome, pruritis vulvae and papular lesions of the vulva ${ }^{6}$. The broad differential diagnosis includes: lichen simplex chronicus, Fox-Fordyce angiokeratomas, condylomas, scabies, contact dermatitis, lichen sclerosis, etc. This highlights the importance of optimizing diagnostic tools such as dermatoscopy and performing early histological study ${ }^{7,8}$.

Although the gold standard for diagnosis is histopathology and dermoscopy features of syringomas - still barely elucidated-, can help to identify the tumor. Dermoscopic findings include multiple, oval and different-sized yellow structures with a diffuse light-brown "network-like" structures. These yellow enlargements may be correlated with the ductal eccrine proliferation and the dense stroma seen in histopathology $y^{9,10}$. Lallas et al. describe the dermatoscopy of eruptive syringomas with the presence of areas without structures on a yellowish background with few linear thin vessels. In our study, the dermoscopy revealed yellow-brown background with a light brown network on the surface in the most lesions. The histophatology with the small eccrine ductal structures, confirms the gold standard diagnosis.

\section{Gonclusion}

Due to the difficult characterization of the syringomas that make it confuse with other pathologies, it is necessary to perform a good physical examination, taking into account the atypical locations, such as in the chest and arms, associated with a good observation of the dermatoscopy with yellow-brown backgrund, as we recorded in our study. More descriptive and association studies are lacking for the future.

In memoriam al Dr. Sergio Alvarez QEPD

\section{REFERENCIAS}

1. Resende C, Araújo C, Santos R, Pereira T, Brito C. Late-onset of eruptive syringomas: a diagnostic challenge. An Bras Dermatol 2015;90:239-41.

2. Tsunemi Y, Ihn H, Saeki H, Tamaki K. Generalized eruptive syringoma.Pediatric Dermatology 2005; 22:492-493.

3. Pérez A, Ruiz I, Delgado S, Alonso T, Ingelmo J. Vulvar syringoma: A rare case of vulvar pruritus. Actas Dermosifiliogr 2008;99:573-82

4. Corazza M, Borghi A, Minghetti S, Ferron P, Virgili A. Dermoscopy of isolated syringoma of the vulva. J Am Acad Dermatol 2017; 76:S37-9.

5. Hayashi Y, Tanaka M, Nakajima S, Ozeki M, Inoue T, Ishizaki S, Fujibayashi M. Unilateral linear syringoma in a Japanese female: dermoscopic differentiation from lichen planus linearis. Dermatol Reports. 2011; 3(3):e42

6. Friedman SJ, Butler DF. Syringoma presenting as milia. J Am Acad Dermatol 1987;16:310-314.

7. Türkyilmaz C, Tuncay M, Atakul T, Batukan C, Akgün H. Effective treatment of Vulvar syringoma with topical steroid: A case report. Erciyes Medical Journal 2009;1:S41-S45.

8. Miranda J, Shahabi S, Salih S, Bahtiyar O. Vulvar syringoma, report of a case and review of the literature. Yale Journal of Biology and Medicine. 2002; 75:207-2010; J Am Acad Dermatol 2003; 48: 735739 .

9. Huang Y, Chuang Y, Kuo T, Yang L, Hong H. Vulvar syringoma: A clinocopathologic and immunohistologic study of 18 patients and results of treatment.

10. Kempf W, Hantschke M, Kutzner H, Burgdorf W. Dermopathology. Steinkopff Verlag; 2008

11. Lallas A, Moscarella E, Argenziano G. Dermoscopy of uncommon skin tumours. Australasian Journal of Dermatology, 2014; 55:53-62. 